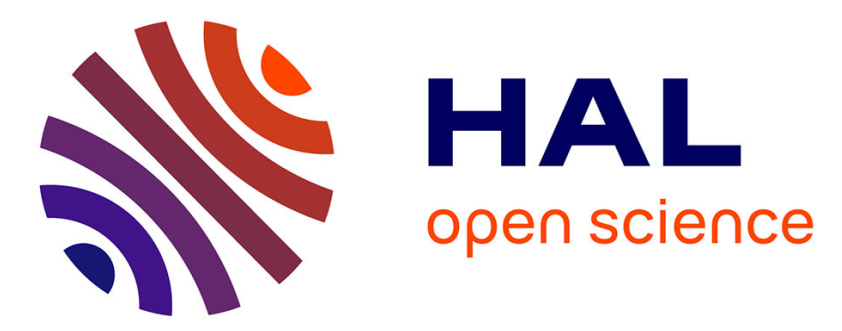

\title{
Measuring and evaluating education quality of future public administration employees at private university in the Slovak Republic
}

\author{
Luboš Cibák, Vojtech Kollár, Stanislav Filip
}

\section{To cite this version:}

Luboš Cibák, Vojtech Kollár, Stanislav Filip. Measuring and evaluating education quality of future public administration employees at private university in the Slovak Republic. Insights into Regional Development, 2021, 3 (2), pp.213 - 228. 10.9770/ird.2021.3.2(4) . hal-03583927

\section{HAL Id: hal-03583927 \\ https://hal.science/hal-03583927}

Submitted on 22 Feb 2022

HAL is a multi-disciplinary open access archive for the deposit and dissemination of scientific research documents, whether they are published or not. The documents may come from teaching and research institutions in France or abroad, or from public or private research centers.
L'archive ouverte pluridisciplinaire HAL, est destinée au dépôt et à la diffusion de documents scientifiques de niveau recherche, publiés ou non, émanant des établissements d'enseignement et de recherche français ou étrangers, des laboratoires publics ou privés.

\section{(c)(1)}

Distributed under a Creative Commons Attribution| 4.0 International License 
INSIGHTS INTO REGIONAL DEVELOPMENT

ISSN 2669-0195 (online) http://jssidoi.org/IRD/

2021 Volume 3 Number 2 (June)

http://doi.org/10.9770/IRD.2021.3.2(4)

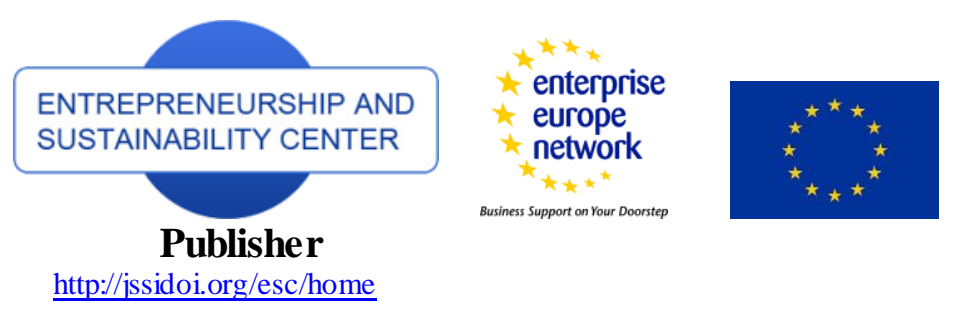

\title{
MEASURING AND EVALUATING EDUCATION QUALITY OF FUTURE PUBLIC ADMINISTRATION EMPLOYEES AT PRIVATE UNIVERSITY IN THE SLOVAK REPUBLIC*
}

\author{
Luboš Cibák ${ }^{1}$, Vojtech Kollár ${ }^{2}$, Stanislav Filip ${ }^{3}$ \\ 1,2,3 School of Economics and Management of Public Administration, Furdeková 16, 85104 Bratislava, Slovak Republic \\ E-mails: ${ }^{1}$ lubos.cibak@vsemvs.sk; ${ }^{2}$ vojtech.kollar@vsemvs.sk; ${ }^{3}$ stanislav.filip@vsemvs.sk
}

Received 15 December 2020; accepted 10 April 2021; published 30 June 2021

\begin{abstract}
The private School of Economics and Management of Public Administration in Bratislava educates experts for public administration in Slovakia through bachelor and master study programs. The high percentage of graduates employed in governing bodies and municipalities proves the high quality of theoretical and practical level of education. The scientific and pedagogical personnel and particulary the ingenious and comprehensive education quality control system has its share in achieving distinct results. The authors of this article present a well-established system of education quality. They analyze and evaluate the system of quality measuring and evaluating using internal tools and procedures. The article pays special attention to the external form of quality measurement and evaluation through independent international institution Trendence. Criteria and areas of evaluation are assessed throughout the university, Slovakia, and Europe, which is presented by more than 1,000 higher education institutions.
\end{abstract}

Keywords: Public administration; employer of public administration; quality measurement

Reference to this paper should be made as follows: Cibák, L., Kollár, V., Filip, S. 2021. Measuring and evaluating education quality of future public administration employees at private university in the Slovak Republic. Insights into the Regional Development, 3(2), 213-228. http://doi.org/10.9770/IRD.2021.3.2(4)

JEL Classifications: I 21, I 23, I 24, I 28

\section{Introduction}

The European Higher Education Area (EHEA) is the result of the political engagement of 48 countries that have gradually built up the education area using shared tools over the last twenty years. Ongoing higher education reforms in european countries are based on common key values - such as freedom of expression, the autonomy of institutions, independent student unions, academic freedom, free movement of students and staff. Through this process, countries, institutions, and stakeholders of the European area constantly adjust their higher education

\footnotetext{
* The paper is the output of a scientific project IGA 1/2018-M "Benchmarking model - Intelligent Portfolio for Quality Measurement and Management of Education at Bulgarian and Slovakia Higher schools". " (Funder: VSEMvs IGA VSEMvs, i.e. School of Economics and Management in Public Administration)
} 
INSIGHTS INTO REGIONAL DEVELOPMENT

ISSN 2669-0195 (online) http://jssidoi.org/jesi/

2021 Volume 3 Number 2 (June)

http://doi.org/10.9770/IRD.2021.3.2(4)

systems, which improves compatibility and strengthen their quality assurance mechanisms. The main goal common for all countries in question is to increase staff and students' mobility and to facilitate the entry of graduates into the labor market. This paper presents selected methods and tools for education monitoring at the university through the standards of the internal system of quality assurance.

\section{Literature review}

The literature review contains publications and legal norms that describe the methodology and standards for evaluating the quality of higher education at the international level, in the EU area, and also in the Slovak Republic.

Description of methods and quality of higher eductions standards at the international level is the topic of (M. Šiškovič, M. Játi, 2015). Publication entitled "What do the international rankings of universities really measure" provides the famous world universities rankings such as ARWU (Shanghai Ranking), QS World University Ranking (QS), and Times Higher Education World University Rankings (THE).

The results of a workshop on the use of benchmarking to improve higher education, which was organized by the European Network for Quality Assurance in Higher Education in Helsinki in 2002, are published by a team of authors (K. Hämäläinen et al., 2002) and entitled "Benchmarking in the Improvement of Higher Education".

The European Center for Strategic Management of Universities has published "A Practical Guide to Benchmarking in European Higher Education" as result of an EU-funded project. The guide recommends benchmarking method as a comparative tool for self-assessment and comparison with key competitors and implementations of the best procedures. (ESMU, 2008).

Further international source literature: (Ross, W. 2018) Comparing and Benchmarking Higher Eeducation System as a Com 14 ${ }^{\text {th }}$ Chapter of Research Handbook on Quality, Performance and Accountability in Higher Education, (U. Swahn, 2004) "International Benchmarking and National Quality Assessment Systems" as a case of Sweden; (J. Urquhart, D. Ellis, A. Woods, 2002). „Benchmarking guidelines for university technical Services “.( Seberová, A., Malčík, M.2009). "School self-evaluation - from theory to practice and research". (Sanders, J. R., Davidson, E.J. 2003). "A Modelfo school evaluation". (Novák, M. 2012). Overview of key phenomena, properties, assessed activities of self-evaluation

International publications of this sort could also include publication, which is the result of the mutual research of the University of Transport Todor Kableshkov - Sofia, Bulgaria, and School of Economics and Management of Public Administration in Bratislava, Slovakia. A team of authors led by D. Todorova et all. (2019) "International Business - Benchmarking of Nordic Business Studies in Higher Education" (U. Swahn, 2004) published a monograph entitled "Benchmarking model - Intelligent Portfolio for Quality Measurement and Management of Education at Bulgarian and Slovakia Higher schools".

An interesting problematics of racial equality in the context of improving the education quality at universities is presented by J. Rodrigues, N.G.L. Rodrigues and K. Feeman, (2018) in the article "Students Evaluation of teaching: prenology in the 21st."

The topic of the IT technologies contribution to the quality of higher education is discussed by M. Lytras, (2018) in the article "Technology-Enhanced learning research in Higher Education".

The Standards and guidelines for quality assurance in the European Higher Education Area were adopted by the European Association for Quality Assurance in Higher Education (ENQA), the European Students' Union (ESU), 


\section{INSIGHTS INTO REGIONAL DEVELOPMENT}

ISSN 2669-0195 (online) http://jssidoi.org/jesi/

2021 Volume 3 Number 2 (June)

http://doi.org/10.9770/IRD.2021.3.2(4)

the European University Association (EUA), the European Association of Institutions in Higher Education (EURASHE) in cooperation with Education International (EI), Business Europe and the European Quality Assurance Register for Higher Education (EQAR) and are published in the "Standards and Guidelines for Quality Assurance in the European Higher Educational Area (ESG)".

The general criteria for evaluating the quality of higher education in the Slovak Republic were established by Act of Federal Assembly of Czech and Slovak Federative Republic no. 172/1990 Coll. This legal act has been gradually changed after the independence of the Slovak Republic. The first modification was brought by the Act of the National Council of the Slovak Republic no. 41/1991 Coll. which established military universities. The substantial change was however brought by the Act of the National Council of the Slovak Republic no. 324/1994 Coll. , which amended the original Act no. 172/1990 Coll. Accreditation Commission in Slovakia was established in section 17 as an advisory body of the Government of the Slovak Republic to comment on the quality of higher education institutions by recommending to the Government of the Slovak Republic ability to grant or withdraw university rights. Further adjustments in the Higher Education Institutions law, which took place in 1997 or more precisely in 1999 did not fundamentally change the measurement and assessment of the quality of universities in the Slovak Republic.

Progress in the process of evaluating the quality of higher education was brought by Act of the National Council of the Slovak Republic No. 131/2002 Coll. on higher education institutions. The Accreditation Commission was granted the competence to assess and evaluate the quality of education, research, development, or artistic activities at universities.

The last and rather substantial change in the assessment and evaluation of education quality at universities in the Slovak Republic was brought by the Act of the National Council of the Slovak Republic No. 269/2018 on Quality Assurance in Higher Education. This act defined new rules on higher education quality assurance in accordance with European standards. Due to the given purpose Accreditation Commission, at that time performing as an advisory body to the Government of the Slovak Republic was dismissed and the Slovak Accreditation Agency was created. This agency has developed and approved Standards for the Internal System, Standards for the Study Program, Standards for the Rehabilitation Procedure, and the Inaugural Procedure.

\section{Objectives and methods}

The paper aims to provide comprehensive information on the importance, goals, procedures, and results of internal and external evaluation of the education quality at private university in the Slovak Republic and compare them with EU policy in the field of education quality. The partial goal of this paper is to create a framework for the profound research and comparison of problematics at other universities within the EU countries (Bulgaria) and third countries in Europe that have shown a lasting interest in joining the EU (Ukraine and Serbia). Regular monitoring and evaluation of study programs provide valuable information to school principalship for decisionmaking processes. Study courses, programs, and teacher evaluations are regularly evaluated with the involvement of students and other stakeholders at the university.

Based on a comparative analysis of these internal evaluation areas, external evaluation, and quality standards of education, partial goals are formulated and aimed at:

- content of study programs concerning the latest research results;

- changing needs of society;

- students' knowledge and competences within the national and European qualification framework;

- efficiency of student evaluation procedures;

- satisfying the needs and contentment of students in relation to the study program; 
INSIGHTS INTO REGIONAL DEVELOPMENT

ISSN 2669-0195 (online) http://jssidoi.org/jesi/

2021 Volume 3 Number 2 (June)

http://doi.org/10.9770/IRD.2021.3.2(4)

-educational environment, support services for subjects of the educational process, and their suitability for the given study program.

\section{The object of the research}

The internal system of quality of higher education includes the policy and processes of internal quality assurance of higher education and creative activity, through which the university fulfills its mission. It creates preconditions for the permanent fulfillment of standards for the internal system and standards for the study program. The standards for the study program are defined as a set of requirements while their fulfillment serves as a condition for the accreditation grant of the study program by an authorized person. Internal system standards are a set of requirements for an internal system and means of its implementation. Quantitative and qualitative indicators are used to evaluate the degree of criteria fulfillment in the process of assessing the compliance of the internal system and accreditation of the study program. The Standards and guidelines for quality assurance in the European Higher Education Area (ESG) were adopted by the Ministers responsible for higher education in 2005 following a proposal drawn by the European Association for Quality Assurance in Higher Education (ENQA) in cooperation with the European Students' Union (ESU), the European Association of Institutions in Higher Education (EURASHE) and the European University Association (EUA). The main objective of the Standards and Guidelines for Quality Assurance in the European Higher Education Area (ESG) is to contribute to a common understanding of quality assurance in learning and teaching are across geographical boundaries by all stakeholders.

The Standards and guidelines have played and will continue to play an important role in the development of national and institutional quality assurance systems throughout the European Higher Education Area (EHEA) and the development of cross-border cooperation. Engagement, especially in external quality assurance processes will enable European higher education systems to demonstrate their quality and increase transparency; the institutions will thus contribute to strengthen trust and will improve mutual recognition of educational attainment, study programs, and other services provided.

Student-focused survey on learning and teaching quality plays an important role in stimulating students' motivation, self-assessment, and involvement in the learning process. Regular monitoring and evaluation of study courses, study programs, and teachers' performance are important for students' progress and future careers. The results of the survey are regularly reviewed and evaluated with the involvement of students and other subjects involved. The obtained information is analyzed and the study programs are adjusted to ensure up-to-dateness.

External quality assurance in various forms can verify the effectiveness of internal quality assurance at a university, act as a catalyst for improvement, and offer new perspectives to the university. At the same time, it provides information on the quality of the activities to the university and the public.

\section{The subject of the research}

School of Economics and Management of Public Administration in Bratislava was established in response to the change of political and social conditions in Slovakia after 1989. Changes in the structure of public administration in the Slovak Republic, especially the establishment of municipal bodies created an urgent need for educated and professionally trained employees at all levels of public administration, i.e. state administration and municipality. This requirement became topical as well at the time of the public administration reform, which was between the years 1998 and 2004 and was one of the key systemic changes carried out in the transformation process in Slovakia. The reform aimed to create the functioning state administration and municipality, which could provide high-quality services to citizens and actual participation in the administration of public affairs. Achievement of this goal required systematic training and an increase in the public administration employee qualifications directly affecting the quality of the work. 


\section{INSIGHTS INTO REGIONAL DEVELOPMENT}

ISSN 2669-0195 (online) http://jssidoi.org/jesi/

2021 Volume 3 Number 2 (June)

http://doi.org/10.9770/IRD.2021.3.2(4)

School of Economics and Management of Public Administration in Bratislava was the first private school in Slovakia providing an offer to satisfy the demand on the education market through comprehensive higher education for public administration employees within the framework of retraining or increase of qualifications. Accredited university study programs have become an opportunity for secondary school graduates to obtain the qualification of a public administration employee and thus gradually replace retiring employees or cover the fluctuation. Current number of nearly 400,000 employees working in state administration and municipality bodies introduced necessity to constantly prepare university-educated and professionally qualified public administration employees for the natural turnover of employees. Only employees well-trained in the theoretical and practical area are able to fulfill the strategic goals of providing quality services to a citizen. The bachelor's and master's degree study program, quality pedagogical staff, education support, and service at VŠEMvs* in Bratislava create preconditions for fulfilling an ambitious goal. The quality of the educational process for the study program Public Administration and Regional Development included in the study field of Economics and Management alignes with the highest requirements.

The main topics of the core knowledge of the economics field of study include the basic principles of economic thinking, the rules of functioning of the economic system, and its components, on a national and international scale, with interaction with economic policy and regional economic relations.

In the field of management, it consist of principles of strategic, tactical, and operational management in the regional environment respecting the functions of management, the legal form of the economic entity, and the rules of the functioning of its individual functional components.

Education quality maintenance and assurance are conditioned by the content of the study program and the range of knowledge, skills, and competencies that the student acquires upon graduating.

\section{Used Methods}

Standard methods of scientific research were applied in the preparation phase of the article. In addition to methods of scientific abstraction and description, scientific methods of analysis and synthesis, comparative methods and specifically benchmarking methods are applied in the article. Statistical survey methods were used for purpose of internal measurement and assessment of the education quality.

\section{Process and steps of the quality management system implementation}

Quality management has been an integral part of the management processes of VŠEMvs in Bratislava since 2014. Within the scope of the Internal Quality System at VŠEMvs in Bratislava, quality monitoring is focused on monitoring the profile of the graduate in the respective cycle of study, focusing on the acquired knowledge, skills, and competencies. (Kollár, V., Polakovič, P., Gasperová, J. 2016).

At the university, internal quality system is built as a set of systems, resources, and information dedicated to maintaining and increasing the education process quality, science, and research, including the experience of students and external entities.

Development of the internal quality system was based on recommendations of the European Association for Quality Assurance, the European excellence model, and process-oriented quality system, which uses norms of ISO 9000 series for building the system and provision, improvement, and measuring the effectiveness. Our university implements the strategy of securing and increasing quality into all processes and activities to meet set goals.

\footnotetext{
${ }^{*}$ School of Economics and Management of Public Administration in Bratislava
} 
INSIGHTS INTO REGIONAL DEVELOPMENT

ISSN 2669-0195 (online) http://jssidoi.org/jesi/

2021 Volume 3 Number 2 (June)

http://doi.org/10.9770/IRD.2021.3.2(4)

Identification of processes and activities at the university is the basis of a process approach to quality management. Its advantage is the continuous management of the links between the individual processes within the system, as well as the management of the combinations and interactions of the processes that this approach provides.

This approach emphasizes the importance of:

- understanding and fulfillment of requirements, demands, and wishes,

- understanding of processes in terms of added value,

- gaining knowledge about the efficiency and effectiveness of processes,

- continuous process improvement based on objective measurements.

We applied the method of planning and monitoring the performance of all processes. The basis is the implementation, measurement, and control of performed activities, which lead to the continuous improvement of transparency, accountability, cooperation, and informedness at the vertical and horizontal levels within the organizational structure of the university.

The main goal of the internal quality system is to develop the quality importance in a way that the system is helpful for:

- education and training of university professionals, who will have knowledge, skills, and competencies that will enable them to successfully enter the labor market in a competitive environment at home and abroad,

- developing knowledge and education based on creative scientific research in the field of public administration, small and medium-sized enterprises, and municipal security to create a basis for ensuring and improving the quality of the educational process and its components,

- strengthening the position of VŠEMvs in Bratislava in its integration into the network of higher education institutions in the Slovak Republic and the European educational and scientific research area.

The quality policy is based on the long-term development plan of VŠEMvs and its updating. The aim of the quality policy in common activities and in all areas of VŠEMvs is to achieve the satisfaction of current and future requirements, demands, and wishes of all members of the academic community.

The fundamental tools of the internal quality system are map of processes, internal guidelines, and regulations of university management. The organization of the internal quality system in the horizontal and vertical structure is implemented by connecting the primary, management, and auxiliary processes to the organizational structure of VŠEMvs.

In the process of managing, securing, and improving the education quality policy and in connection with other activities, VŠEMvs promotes:

- Open access at all cycles and forms of education, by applying the principle of equal opportunities for all those interested in studying.

- Ensuring student satisfaction by understanding their current and future needs, demands, and desires.

- Innovation of existing accredited study programs and development of new study programs needed for the education and labor market.

- Strengthening the pride of students and future graduates of VŠEMvs, by creating a motivating environment for the involvement of students and employees in the fulfillment of set goals in the long-term plan of the university. 


\section{INSIGHTS INTO REGIONAL DEVELOPMENT}

ISSN 2669-0195 (online) http://jssidoi.org/jesi/

2021 Volume 3 Number 2 (June)

http://doi.org/10.9770/IRD.2021.3.2(4)

- Creating conditions for personal and professional growth of each member of the academic community of VŠEMvs in Bratislava.

- Internationalization of education, improvement of science and research, cooperation and partnerships with other institutions from the regions of Slovakia and foreign institutions as well as with universities at home and abroad.

- Motivating students and staff for further education, strengthening loyalty and good relations between members of the academic community of VŠEMvs in Bratislava,

- Planning, monitoring, evaluating, and improving the quality of all processes and activities in response to the dynamically evolving requirements, talent, and excellence of stakeholders.

In the process of building the internal system of quality assurance and improvement at VŠEMVS in Bratislava, we identified three groups of processes fig. 1 .

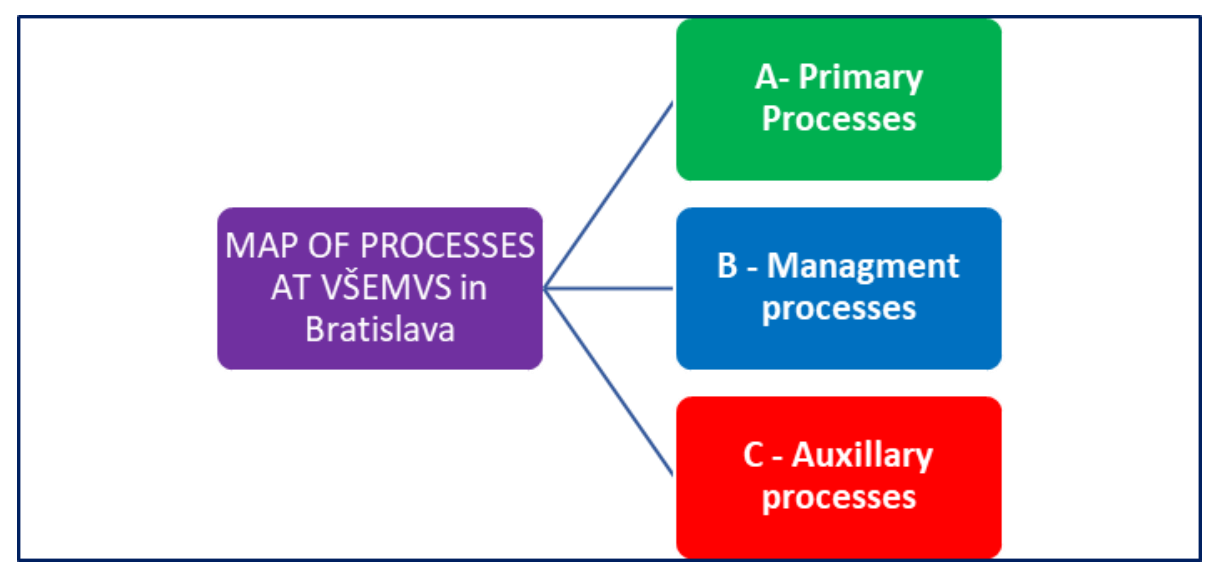

Fig. 1. Map of processes at VŠEMVS in Bratislava Source: internal data

P1. Educational activity: focused on the subjects of the educational process:

PB1, PM1, PR, PLL -processes of bachelor's, master's study, rigorous procedure, and lifelong learning.

P2. Scientific research activity - processes of creative activity, which include comprehensive problematics of research and development, science and research projects, and transformation and development projects.

P3. Cooperation with practice - processes of cooperation with educational, scientific, and research departments at home and abroad. Economic entities and organizations of state administration and self-government.

M. Management processes - focused on the implementation of the vision, strategy, and the goals and tasks of the long-term plan of the university.

M1 Strategic management

M2 Operational management

M3 Internal audits

A. Auxiliary processes - support for the creation, updating, and collection of information, decision-making, and implementation of corrective measures. 
A1 Creation of study programs

A2 Update of study programs

A3 Information system management

A4 Admission of students

A5 Admission of foreign students

A6 Review of decisions

A7. Monitoring, analysis, and improvement

The advantage is the continuous control of the links between the individual processes within their system, as well as the control of the combinations and interactions of the processes that this approach provides. Such approach determines the importance of:

-understanding and meeting the requirements, demands, and desires,

-understanding the processes in terms of added value,

-acquiring knowledge about the efficiency and effectiveness of processes,

-continuous process improvement based on objective measurements.

The method of planning and monitoring the performance of processes can be applied to all processes. Essential is the implementation, measurement, and control of activities performed, which lead to the continuous improvement of transparency, accountability, cooperation, and information at the vertical and horizontal levels within the organizational structure of VŠEMvs.

Internal quality system procedures in the field of quality assurance and improvement are developed and applied in the following areas:

a) creation, approval, monitoring, and regular evaluation of study programs, which are developed in the primary process of bachelor's and master's studies, auxiliary and management processes focused on creating, updating and auditing study programs, monitoring student satisfaction with the educational process, which is carried out by questionnaire survey,

b) defining of descriptors, criteria and rules for student evaluation elaborated in the study regulations, the primary, management and auxiliary process focused on monitoring, analysis, and improvement,

c) ensuring the quality of university teachers through their selection according to the criteria for the positions of university employees at VŠEMvs and specifying the job responsibilities of employees in the positions of professor, associate professor, and professional assistant in publication, scientific research, and other creative activities,

d) providing material, technical, and information resources to support education and publishing of necessary information about students and graduates,

e) collection, analysis, use, and publication of current information necessary for effective management, implementation, and improvement of study programs through the academic information system and its software support in education and self-study, e-learning, distance learning, etc.

\section{Internal measurement and evaluation of the education quality}

Monitoring and evaluation of the education quality at VŠEMvs in Bratislava is carried out according to internal regulations and criteria, which are part of:

-Internal quality assessment regulation at VŠEMvs.

-Statute of the Council for the education quality at VŠEMvs.

-Criteria for filling the positions of university employees at VŠEMvs.

-Concretization of work duties of VŠEMvs employees in Bratislava in the positions of professor, associate professor, and professional assistant in publishing and scientific research activities. 
INSIGHTS INTO REGIONAL DEVELOPMENT

ISSN 2669-0195 (online) http://jssidoi.org/jesi/

2021 Volume 3 Number 2 (June)

http://doi.org/10.9770/IRD.2021.3.2(4)

The content of the previously described documents corresponds with the requirements for knowledge, skills, and competencies of graduates of the Public Administration study program.

Procedures for creating study programs are regulated in the activities of auxiliary processes of the internal quality system manual. The evaluation is carried out in the internal environment of the university by monitoring students' satisfaction with the courses of the relevant study program in various cycles and forms of study, by measuring and controlling activities in the educational process, which lead to the continuous improvement of transparency, accountability, cooperation, and information at the vertical and horizontal level within the organizational structure of VŠEMvs.

To compare the increasing requirements in specific cycles of higher education within the main processes at VŠEMvs, we applied the Dublin descriptors to their content focus, while using them to describe the level of education and present the requirements for specific cycles of education with the determination of evaluation criteria and the method of allocating and accumulating credits. We paid attention to the optimization of the hourly workload of students within the specific cycles of study in accredited study programs, by defining the credit subsidy for compulsory, compulsory elective, and elective subjects in full-time and distance study form.

Preparation of the methods for the implementation of courses for the full-time and combined method of study according to their extent, the credit method for the realization of the subject, and the optimal student workload. At the same time, the optimization of proven parameters also determines the requirements for the content, organizational, and qualification level.

Monitoring of the pedagogical process in the form of inspections, evaluation of students' entrance tests, and evaluation of students after completing the courses is carried out at institutes and their departments according to the internal quality system. The inspection activity controls the pedagogical process at lectures, seminars, exercises, and consultations and is carried out by the pedagogical staff of the university.

The aim of course evaluation is to assess the content focus of the course, placement to the structure of the study plan, the form and scope of education, the topicality of the presented problematics, the availability of study literature. The evaluation of study programs is focused on the assessment of the content, the continuity of subjects and their credit evaluation, courses in foreign languages, the offer of compulsory elective and elective courses, the study program with the requirements of practice, and current knowledge.

Monitoring the quality of education by students in the relevant semester of the academic year is carried out through a questionnaire survey online via the Internet

http://bit.ly/1jmUNee.

PUBLIC ADMINISTRATION courses evaluation https://docs.google.com/forms/d/e/1FAIpQLScQQSQdwXOxLPr_qUnCbASGAf2Y8iyu8wQ102ous1BvKwQ5V Q/viewform

Evaluation of the STUDY PROGRAM

- https://docs.google.com/forms/d/e/1FAIpQLSdo4rMN9qbDmu94UHup1NpaS-ZK9bHa0uWVpw_i_H$\underline{3 \mathrm{Ka} 8 \mathrm{XZw} / \mathrm{viewform}}$

Evaluation of the teacher's PEDAGOGICAL PERFORMANCE https://docs.google.com/forms/d/e/1FAIpQLScKaxAcgqZB_x4nR7sVyyLR1uNmvfbpxzmXeJZRrqtQiilu1A/vie $\underline{\text { wform }}$ 


\section{INSIGHTS INTO REGIONAL DEVELOPMENT}

ISSN 2669-0195 (online) http://jssidoi.org/jesi/

2021 Volume 3 Number 2 (June)

http://doi.org/10.9770/IRD.2021.3.2(4)

The highest number of students at VŠEMvs in the time period form 2012 to 2019 was in 2012 at 4549; until 2011, the number of students had an overall upward trend, but since 2012 the development has taken a downward trend concerning several factors (demographic changes, study opportunities at several universities and in all countries,...). In 2018 , compared to the previous year, the total number of students decreased by 272 , which is by $15.4 \%$. When comparing the change in numbers in the full-time form of study, there was an increase from 1,279 in 2018 to 1,435 in 2019, which is 156 students more. In distance form, there was a decrease from 490 in 2018 to 62 in 2019, which represents 428 students. This was caused by the introduction of a full-time study form through the combined method, which many first- and second-year students used.

Regarding the evaluation of specific cycles of study, the development of the number of students at the 1. cycle of the study had a more balanced course until 2011 after which there is a relatively strong declining trend. In 2019, compared to 2018, there was an increase in the number of 26 students (approximately 3\%).

In the 2nd cycle of study, since 2012 the development of the number has been slightly cyclical and slower declining and in 2019, compared to the previous year, a decrease of 298 students was recorded (approximately $32.5 \%$ ) (Table 1 and Table 2).

Table 1. Development of the number of students since 2012 in the 1st and 2nd cycle of study (full-time and distance study together)

\begin{tabular}{|c|c|c|c|c|c|c|c|c|}
\hline year & $\mathbf{2 0 1 2}$ & $\mathbf{2 0 1 3}$ & $\mathbf{2 0 1 4}$ & $\mathbf{2 0 1 5}$ & $\mathbf{2 0 1 6}$ & $\mathbf{2 0 1 7}$ & $\mathbf{2 0 1 8}$ & $\mathbf{2 0 1 9}$ \\
\hline 1st cycle & 3066 & 2847 & 2181 & 1717 & 1321 & 985 & 854 & 880 \\
\hline 2nd cycle & 1483 & 1566 & 1456 & 1263 & 1302 & 1184 & 915 \\
\hline Total & 4549 & 4413 & 3637 & 2980 & 2623 & 2169 & 1769 & 1497 \\
\hline
\end{tabular}

Source: internal data

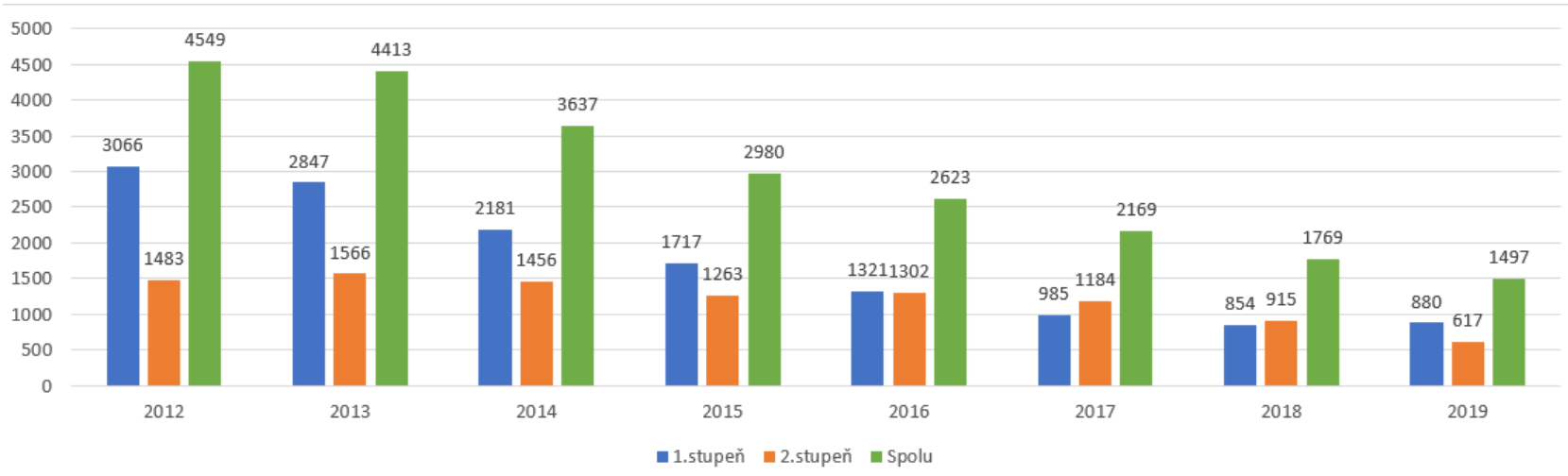

Fig. 2. Graphic representation of the development of the number of students since 2012 by study cycles (full-time and distance study together)

Source: internal data 
Table 2. Monitoring of student assessment 1st and 2nd cycle of study

\begin{tabular}{|c|c|c|c|c|c|c|}
\hline $\begin{array}{l}\text { Number of } \\
\text { Yeak }\end{array}$ & COURSES & STUDENTS & $\begin{array}{l}\text { STUDY } \\
\text { PROGRAMS }\end{array}$ & STUDENTS & PEDAGOGUES & STUDENTS \\
\hline 2014 & 14 & 1018 & 2 & 1018 & 31 & 1081 \\
\hline 2015 & 22 & 1212 & 2 & 1212 & 34 & 1212 \\
\hline 2016 & 25 & 988 & 2 & 988 & 33 & 988 \\
\hline 2017 & 27 & 1009 & 2 & 1009 & 32 & 1009 \\
\hline 2018 & 22 & 897 & 2 & 897 & 33 & 897 \\
\hline 2019 & 19 & 988 & 2 & 988 & 31 & 988 \\
\hline SPOLU & 129 & 6112 & & 6112 & 194 & 6112 \\
\hline
\end{tabular}

Source: internal data

Between 2014 and 2019, 6,112 students participated in the survey and evaluated 129 subjects of the 1st and 2nd cycle of study. Most students involved were in the full-time form of study. Students directly involved in the evaluation of courses reached $4.5 \%$ of the total number of full-time students in the observed period.

On average, $2.2 \%$ to $5.9 \%$ of full-time or distance students participated in the evaluation of teachers and study programs of the 1st and 2nd cycle of study. On average, the number of respondents indicates that the results of the survey were significant. The management of VŠEMvs pays attention to surveys and regularly discusses comments and proposals at the level of diocesan and self-governing levels of the university.

\section{External measurement and evaluation of education quality}

We have been using the method of external evaluation of the education quality at VŠEMvs in Bratislava since 2010. VŠEMvs accepted the offer of the international company Trendence based in Berlin to participate in an independent international survey called Gradue Barometer.

In the period from 2010 to 2016, 2542 VŠEMvs students participated in the survey. The most, 660 of them were involved in the 2012 survey and the least, only 169 respondents in 2011.

On average, however, the participation was $9.4 \%$ per year, which indicates that the results of the survey were credible. This was also the reason why the management of VŠEMvs is acquainted with the results of the survey and takes measures to improve the assessed situation (see Table 3). 
INSIGHTS INTO REGIONAL DEVELOPMENT

ISSN 2669-0195 (online) http://jssidoi.org/jesi/

2021 Volume 3 Number 2 (June)

http://doi.org/10.9770/IRD.2021.3.2(4)

Table 3. Overview of VŠEMvs' participation in the Gradue Barometer survey in the years 2010 to 2016

\begin{tabular}{|c|c|c|c|c|c|c|c|}
\hline Indicator & 2010 & 2011 & 2012 & 2013 & 2014 & 2015 & 2016 \\
\hline Number of participating countries & 24 & 24 & 27 & 27 & 27 & 24 & 24 \\
\hline $\begin{array}{l}\text { Total number of participating universities } \\
\text { within Europe }\end{array}$ & 850 & 1077 & 950 & 1057 & 1000 & 952 & 930 \\
\hline Total number of students involved & 220000 & 310945 & 343796 & 317617 & 302261 & 281479 & 300000 \\
\hline $\begin{array}{l}\text { Number of respondents from economic } \\
\text { schools }\end{array}$ & 71545 & 96431 & 123479 & 105442 & 94991 & 98837 & 106475 \\
\hline $\begin{array}{l}\text { Number of students of economic schools } \\
\text { from the Slovak Republic }\end{array}$ & 2355 & 2392 & 1870 & 2999 & 2073 & 1485 & 1554 \\
\hline Number of VŠEMvs students & 381 & 169 & 424 & 660 & 312 & 290 & 307 \\
\hline Total number of VŠEMvs students & 4330 & 4620 & 4549 & 4413 & 3637 & 2980 & 2980 \\
\hline$\%$ of the total number of VŠEMvs students & 8,7 & 3,7 & 9,3 & 14,9 & 8,6 & 9,7 & 10,6 \\
\hline
\end{tabular}

Source: own processing according to the Trendence reports on the results of the 2010-2016 survey

The evaluation system consisted of filling in an anonymous electronic questionnaire, which was available to fulltime and distance students on the VŠEMvs internet portal. Instructions on participating in the survey were developed by Trendence together with a link to the questionnaire. At least 3 months are usually available for data collection, from November to the end of January.

In 2010, areas such as the quality of university education, respondents' views on their future careers, students' views on the attractiveness of employment were evaluated.

Areas as well as specific quality evaluation criteria developed in consideration of the evaluation results. Therefore, it was not possible to evaluate development trends for several years in a row. It was not until 2015 that the number of key areas and individual criteria stabilized. Students - respondents participated in their selection. Currently, the subject of university quality assessment is 10 key areas with a total of 28 criteria. Table 4 shows the results of the VŠEMvs evaluation for 2016.

Table 4. Quality assessment of VŠEMvs according to Graude Barometer 2016

\begin{tabular}{|c|c|c|c|c|}
\hline Field & Indicator & $\begin{array}{c}\text { Europe } \\
{[\%]}\end{array}$ & $\begin{array}{l}\text { Slovakia } \\
{[\%]}\end{array}$ & $\begin{array}{l}\text { V ŠEMvs } \\
{[\%]}\end{array}$ \\
\hline \multirow[t]{4}{*}{ Professors / Teachers } & Professional competencies & 84,9 & 83,1 & 89,1 \\
\hline & Pedagogical competencies & 73,5 & 70,2 & 84,9 \\
\hline & Availability & 70,6 & 67,7 & 72,3 \\
\hline & Motivation and willingness to help & 73,2 & 68,3 & 77,1 \\
\hline \multirow{3}{*}{$\begin{array}{l}\text { Connection of study field with } \\
\text { practice }\end{array}$} & Relevance of study content for practice & 64,5 & 50,4 & 65,3 \\
\hline & Excursions, case studies, lectures by guest speakers & 49,9 & 51,7 & 68,0 \\
\hline & Internship as a part of study (experiences, internship) & 51,6 & 40,0 & 61,5 \\
\hline \multirow{2}{*}{$\begin{array}{l}\text { The international dimension of } \\
\text { the study }\end{array}$} & Lectures in a foreign language (e.g. in English) & 49,7 & 42,8 & 47,7 \\
\hline & $\begin{array}{l}\text { Exchange programs, partnerships with other } \\
\text { universities }\end{array}$ & 66,1 & 65,9 & 74,0 \\
\hline \multirow{3}{*}{$\begin{array}{l}\text { Cooperation of the university } \\
\text { with the private sector }\end{array}$} & Job offers (internships, part-time jobs) & 53,7 & 42,1 & 59,4 \\
\hline & Job / career fairs & 58,3 & 45,8 & 55,8 \\
\hline & Cooperation with companies in research projects & 47,5 & 39,3 & 52,8 \\
\hline Quality availability of IT & Wifi & 74,0 & 69,7 & 68,6 \\
\hline
\end{tabular}


INSIGHTS INTO REGIONAL DEVELOPMENT

ISSN 2669-0195 (online) http://jssidoi.org/jesi/ 2021 Volume 3 Number 2 (June)

http://doi.org/10.9770/IRD.2021.3.2(4)

\begin{tabular}{|c|c|c|c|c|}
\hline infrastructure & Availability and equipment of computer rooms & 68,2 & 68,3 & 60,4 \\
\hline \multirow{4}{*}{$\begin{array}{l}\text { Quality and availability of } \\
\text { libraries }\end{array}$} & Diverse and current offer & 79,3 & 64,7 & 72,4 \\
\hline & Availability of literature & 77,4 & 59,5 & 66,1 \\
\hline & Plenty of space to work in the library & 69,0 & 75,7 & 82,1 \\
\hline & Opening hours & 78,7 & 74,8 & 85,7 \\
\hline \multirow[t]{2}{*}{ Career center and counseling } & Career counseling, job offers & 52,1 & 32,8 & 50,5 \\
\hline & Events (e.g. job/career fairs) & 57,7 & 47,1 & 50,9 \\
\hline \multirow[t]{3}{*}{ Service and advisory } & Transparent authority & 58,9 & 48,0 & 68,7 \\
\hline & Competent staff & 64,8 & 58,6 & 75,4 \\
\hline & Quick response to questions & 64,0 & 56,9 & 73,9 \\
\hline \multirow[t]{3}{*}{ Location } & Transport infrastructure & 71,2 & 76,1 & 83,8 \\
\hline & Possibilities to spend free time, availability of shops & 67,3 & 77,6 & 73,5 \\
\hline & Price level / cost of living (e.g. rents) & 58,4 & 59,3 & 56,0 \\
\hline \multirow[t]{2}{*}{ Student activities } & $\begin{array}{l}\text { Events (e.g. film club, sports activities, parties, } \\
\text { concerts) }\end{array}$ & 69,0 & 72,5 & 71,9 \\
\hline & Higher education policy (student parliament) & 58,8 & 60,5 & 71,2 \\
\hline
\end{tabular}

Source: own processing according to the Trendence Gradue Barometer 2016 report

Evaluations mentioned above provide opportunity to highlight the best evaluation for the areas of professors/teachers, the connection of the study field with practice, and the service and advisory at VŠEMvs. These three key areas of education quality at VŠEMvs shows better evaluation in all criteria compared to the European and Slovak average.

Even development trends of quality assessment are interesting. The number of evaluated criteria, for which we found a match during the years 2013 to 2016, is presented in Table 5.

Table 5. Trends in the evaluation of selected indicators for the years 2013 to 2016

\begin{tabular}{|c|c|c|c|c|c|}
\hline Indicator & 2013 & 2014 & 2015 & 2016 & $\begin{array}{c}\text { Index } \\
2013 / 2016\end{array}$ \\
\hline Professional competences & 80,5 & 67,5 & 88,8 & 89,1 & 1,11 \\
\hline Pedagogical competencies & 79,8 & 72,6 & 85,5 & 84,9 & 1,06 \\
\hline Availability & 70,6 & 69,9 & 88,2 & 72,3 & 1,02 \\
\hline Relevance of study content for practice & 55,7 & 53,4 & 79,9 & 65,3 & $\mathbf{1 , 1 7}$ \\
\hline Excursions, case studies, lectures by guest speakers & & & 62,0 & 68,0 & 1,09 \\
\hline Internship as a part of the study (experiences, internship) & & & 79,9 & 61,5 & $-1,25^{*}$ \\
\hline Lectures in a foreign language (e.g. in English) & & & 51,6 & 47,7 & $-1,08 *$ \\
\hline Exchange programs, partnerships with other universities & 64,3 & 56,0 & 75,6 & 74,0 & 1,15 \\
\hline Job offers (e.g. internships, part-time jobs) & 29,1 & 35,7 & 57,6 & 59,4 & 2,04 \\
\hline Job/career fairs & & & 59,8 & 55,8 & $-1,07 *$ \\
\hline Cooperation with companies in research projects & & & 56,4 & 52,8 & $-1,06 *$ \\
\hline Wifi & & & 65,7 & 68,6 & $1,04 *$ \\
\hline Availability and equipment of computer rooms & 65,1 & 61 & 64,3 & 60,4 & $-1,07$ \\
\hline Diverse and current offer & & & 70,9 & 72,4 & 1,02 \\
\hline
\end{tabular}


INSIGHTS INTO REGIONAL DEVELOPMENT

ISSN 2669-0195 (online) http://jssidoi.org/jesi/

2021 Volume 3 Number 2 (June)

http://doi.org/10.9770/IRD.2021.3.2(4)

\begin{tabular}{|c|c|c|c|c|c|}
\hline Availability of literature & & & 66 & 66,1 & 1,00 \\
\hline Plenty of space to work in the library & & & & 82,1 & - \\
\hline Opening hours & & & 75,5 & 85,7 & $1,13 *$ \\
\hline Career counseling, job offers & & & 54,4 & 50,5 & $-1,7 *$ \\
\hline Events (e.g. career/job fairs) & & & 53,7 & 50,9 & $-1,05 *$ \\
\hline Transparent authorities & & & 67,1 & 68,7 & $1,02 *$ \\
\hline Competent staff & & & 81,3 & 75,4 & $-1,07 *$ \\
\hline Quick response to questions & & & 78,5 & 73,9 & $-1,06 *$ \\
\hline Transport infrastructure & & & 89,9 & 83,8 & $-1,07 *$ \\
\hline Possibilities to spend free time, availability of shops & & & 80,2 & 73,5 & $-1,09 *$ \\
\hline Price level / cost of living (eg rents) & 46,8 & 56,7 & 63,2 & 56,0 & 1,19 \\
\hline Events (e.g. film club, sports activities, parties, concerts) & 47,2 & 62,2 & 73,5 & 71,9 & 1,52 \\
\hline Higher education policy (student parliament) & & & 81,4 & 71,2 & $-1,14 *$ \\
\hline
\end{tabular}

* Index for the years 2015/2016

Source: own processing according to the Trendence reports on the results of the 2010-2010 survey

Data in the table hint a positive evaluation trends in the quality of teachers, in connection with the study program with practice, offers of part-time jobs for students. There is a slight decrease in the evaluation in the provision of student internships, the provision of lectures in a foreign language, career counseling, and in cooperation with companies. These trends are observable in the Gradue Barometer reports for the last two years as well as in the European and Slovak evaluation.

\section{Conclusions}

Higher education has developed rapidly in Europe and has responded to swiftly changing demands. In Europe, the level of education is constantly increasing, a comprehensive picture of the life we live in and in which we prepare generations for their future. Our goal is the success of our students. Quality education for students is an opportunity to develop the skills and knowledge at the high level that our societies require. Thanks to the Bologna Process and the Erasmus + program, students have more study and job opportunities abroad. Mutual cooperation and sharing of common topics in a changing environment is an opportunity for a new quality in education and for finding and answering questions. How do we recognize and reward good education? What does a good research mean and how it can be used in education? How do we ensure that young people have equal access to quality education and that they will complete higher education successfully? How do we remove obstacles of courses acceptation process and education at specific cycles? And how do we increase the relevance of higher education programs for the labor market? The Bologna Process gives European countries an opportunity to discuss these challenges. This paper asks such questions and creates a space for cooperation and critical dialogue.

The Bologna Process emphasizes Europe's potential to set high standards for modern and relevant education providing. The Bologna Process inspired us in the preparation and implementation of a cooperation project between higher education institutions in Bulgaria, Serbia, Ukraine, and Slovakia.

The main goal of the project is to define, identify, monitor, and evaluate key indicators of quality measuring and management of education through a benchmarking model and based on the comparison of the result to assess the competitiveness of education in the European education market with a focus on selected fields and programs. It is important to recognize the fact that today, more than ever, the European Union must focus on the countries 


\section{INSIGHTS INTO REGIONAL DEVELOPMENT}

ISSN 2669-0195 (online) http://jssidoi.org/jesi/

2021 Volume 3 Number 2 (June)

http://doi.org/10.9770/IRD.2021.3.2(4)

preparing for EU accession - which is also our mission. Our efforts are to bring European institutions of higher education, researchers, and students closer together and connect them.

\section{References}

European Association for Quality Assurance in Higher Education (ENQA). 2015. Standards and Guidelines for Quality Assurance in the European Higher Educational Area (ESG). Brussels. ISBN: 978-9-08-168672-3.p.

European Commission/EACEA/Eurydice, 2018. The European Higher Education Area in 2018: Bologna Process Implementation Report. Luxembourg: Publications Office of the European Union, EC-01-18-252-EN-N ISBN 978-92-9492-740-8.

European guide to mutual quality evaluation (peer review) in vocational education and training. Peer review in initial VET Projekt Leonardo da Vinci (AT/04/C/F/TH-82000) ISBN 978-3-901966-07-1 öibf-Österreichisches Institut für Berufsbildungsforschung Austrian Institute for Research on Vocational Training p. 51010 Vienna Austria

European Centre for Strategic Management of Universities (ESMU) 2008.Bechmarking European Higher Education. Findings of a twoyea EU - funed project. Inn.: https://www.ehea.info/media.ehea.info/file/Transparency/75/1/benchmarking_report_1101_607751.pdf

Hämäläinen, K. at. al. 2002. Benchmarking in the Improvement of Higher Education. ENGA. Report. Heksinky. ISBN 951-98680-6-2 (paperbound) p. 38.

Kollár, V., Polakovič, P., Gasperová, J. 2016. Systems of controlled education, important support of the education proces., In: Studia commercialia Bratislavensia: Scientific journal of the Business Faculty of the University of Economics in Bratislava, Volume 9, Issue 34, pages 154-159. ISSN 1337-7493

Lytras, M. 2018. Technology-enhanced learning research in higher education: A transformative education primer (Editorial). In: Computers in Human Behavior. Volume 109, Article number 106350. ISSN: 0747-5632

Novák, M. 2012. Overview of key phenomena, properties, assessed activities of self-evaluation. In: School work self-assessment model. Background studies on CD. Bratislava: State School Inspectorate. ISBN 978-80-971114-0-3.

Rodrigues, J. Rodrigues, N.G.L., Feeman K. 2018. Students Evaluation of teaching: prenology in the 21 st. In Race Ethnicity and Education. Volume 23, Issue 4, 3 July 2020, Pages 473-491. ISSN: 1361-3324E-ISSN:1470-109

Ross, W. 2018. Comparing and Benchmarking Higher Eeducation System as a $14^{\text {th }}$ Chapter of Research Handbook on Quality, Performance and Accountability in Higher Education. ISBN: 9781785369742. https://doi.org/10.4337/9781785369759. Pages: c 616

Sanders, J. R., Davidson, E.J. 2003. A Modelfo school evaluation. In: International Handbook of Education Evaluation, part two. Dordrecht: Kluver Academic Publishers. ISBN 1-4020-0849-X

Seberová, A., Malčík, M. 2009. School self-evaluation - from theory to practice and research. Ostrava: University of Ostrava. ISBN 97880-7368-759-5.

Standards and Guidelines for Quality Assurance in the European Higher Education Area (ESG). 2015. Brussels, Belgium. ISBN 978-8089354-75-7. P.

Swahn, U. 2004. International Benchmarking aand nationality Assessment System: The case of Sweden. 10. 173-192. https://doi.org/10.1023/B:TEAM.0000044781.29496.83

Todorova, D., Gergva, N., Hristova, M., Kollár, V., Filip, S., Filipová, L. 2019. Benchmarking model - Inteligent Portfolio for Quality Measurement and Management of Education at Bulgarian and Slovakia Higher schools. University of Transport Todor Kableshkov. ISBN 978-954-12-0260-9 p.242. Please mention in the text

Urquhart, J., Ellis, D., Woods, A. 2002. Benchmarking guidelines for university technical Services. Brisbane: Griffith University. Available at: http://www.busimprove.com/urquhart-Benchmarking\%20technical\%20-mSp\%20edit.pdf 
INSIGHTS INTO REGIONAL DEVELOPMENT

ISSN 2669-0195 (online) http://jssidoi.org/jesi/

2021 Volume 3 Number 2 (June)

http://doi.org/10.9770/IRD.2021.3.2(4)

\section{Acknowledgements}

The paper is the output of a scientific project IGA 1/2018-M ,, Benchmarking model - Intelligent Portfolio for Quality Measurement and Management of Education at Bulgarian and Slovakia Higher schools". " (Funder: VSEMvS IGA VSEMvs, i.e. School of Economics and Management in Public Administration)

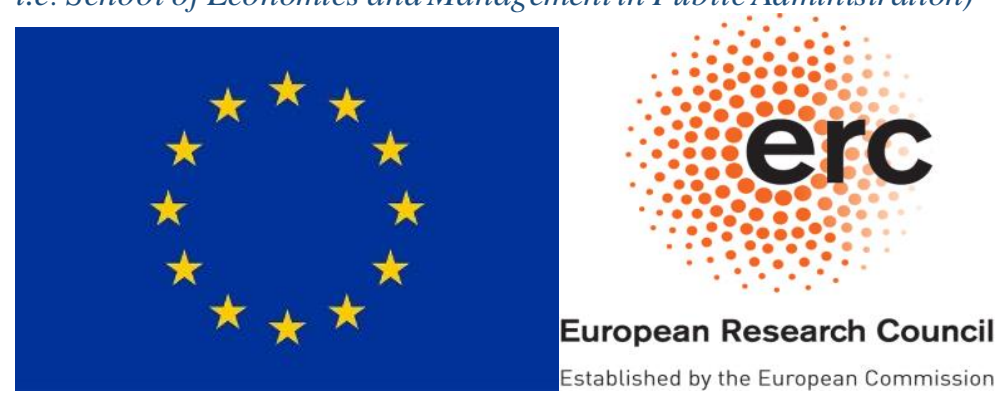

Ĺuboš CIBÁK, Assoc. prof. Ing. PhD. MBA is Chairman of the Management Board of the School of Economics and Management in Public Administration in Bratislava, Slovak Republic and head of Department of the Managerial Informatics. His research and publication activities are focused on management, informatics systems, investment protection and business law.

ORCID ID: https://orcid.org/0000-0003-3881-7924

Vojtech KOLLÁR, Prof. Ing. Phd., is the First Vice-rector and Vice-rectorfor Science and Research an teacher of the School of Economics and management in Public Administration in Bratislava.As a professor, he works in the field of trade and marketing, where he has been inaugurated at the University of Economics in Bratislava. In the field of pedagogy and research, he is concerned with product policy, product quality and production, innovation management, product management, non-tariff barriers to trade, integrated management system, environmental quality management system and product and production competitiveness. $\mathrm{He}$ is the author and co-author of university textbooks, monographs and encyclopaedias published at home and abroad, several dozen university textbooks, scientific and professional articles and articles.

Researcher ID: 9738858000

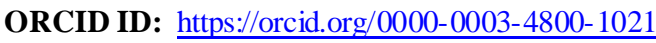

Stanislav FILIP, Assoc prof. Ing. PhD. is the Vice-Rector for foreign affairs an teacher of the School of Economics and management in Public Administration in Bratislava. His text books, monographs and scientific papers deal with the Risk and crisis managemtn in public sector, international crisis management and public administration at the national and EU level. He is succesfull leader and manager of the several scientific projects with support from the EU structural funds. He also organise and control international colaboration and Erasmus plus program with the high educational and research institutions in abroad.

Researcher ID: F-7984-2017

ORCID ID: https://orcid.org/0000-0003-3000-9383

Make your research more visible, join the Twitter account of INSIGHTS INTO REGIONAL DEVELOPMENT: @IntoInsights

Copyright (C) 2021 by author(s) and VsI Entrepreneurship and Sustainability Center

This work is licensed under the Creative Commons Attribution International License (CC BY).

http://creativecommons.org/licenses/by/4.0/ 